International Journal of English Literature and Social Sciences
Vol-6, Issue-2; Mar-Apr, 2021

\title{
The Cosmovision of Students Participating in a Research in Portuguese Public Universities
}

\author{
Rúbia Fonseca Ferreira ${ }^{1}$, Armando Loureiro ${ }^{2}$
}

${ }^{1} \mathrm{PhD}$ in Educational Sciences, Post-Doctoral Student in Educational Sciences Department of English Literature, University of Trás os Montes and Alto Douro, Portugal

${ }^{2} \mathrm{PhD}$ in Educational Sciences, School of Human and Social Sciences, faculty, University of Trás os Montes and Alto Douro-Portugal

Received: 27 Jan 2021; Received in revised form: 11 Mar 2021; Accepted: 09 Apr 2021; Available online: 28 Apr 2021 (C)2021 The Author(s). Published by Infogain Publication. This is an open access article under the CC BY license (https://creativecommons.org/licenses/by/4.0/).

\begin{abstract}
In order to identify aspects of the University students' worldview. Use a qualitative crosssectional approach, with the ability to answer in relation to your position, position of the 3 universal questions, and content analysis using the word cloud. Sample from a student from 10 of the 13 public universities.
\end{abstract}

Keywords- worldview, university students, students.

\section{INTRODUCTION}

Does the world view live in the head or in the whole man? Does she live in the hours of the proclamation or in the quiet hours of the private time of her life? Does he use it or surrender to it? What counts is the person's existential responsibility to get hold of a worldview. (Buber, 1962, p.815)

Worldview (overview of the world). From the general sum of knowledge, philosophers organized, systematically or not, a kind of general panorama of all knowledge, forming a totality of vision, a coordination of opinions intertwined with each other. Particular way of perceiving the world, generally, taking into account human relationships, seeking to understand philosophical issues (human existence, life after death, etc.); conception or worldview (Etm. cosm (o) + vision). Cosmos - from the Greek kosmos means order, as opposed to Chaos (Kaos), disorder. Which translates the ideas of world, universe (J. Machado, 1967, p.712).

Schaeffer (2013), said that comosvision "is the filter through which a person sees the world" (J. Machado, 1967, p.712).

Bottom of the bottom on which a view of the world lands, depending on what kind of roots it has, air roots or earth roots, it decides what flows towards it in terms of nutritional reality, it decides the content of the your reality and hence, the confidence of your performance. (Buber, 1962, p.814)

In the same sense, Geisler and Bocchino (2003) claim that worldview is the lens through which people see the world.

The worldview is analogous to the intellectual lens through which people see reality and that the color of the lens is a strongly determining fact that contributes to what they believe about the world. Furthermore, a worldview is a philosophical system that seeks to explain how facts in reality relate to and adjust to each other. Once the lens components are brought together, it will focus on the general plane of reality that gives a structure in which the smaller parts of life harmonize. In other words, the worldview gives shape or color to the way we think and offers the interpretative condition to understand and explain the facts of our experience. (Geisler \& Bocchino, 2003, p.53)

Education, like any other human activity, cannot escape the domain of metaphysics, because metaphysics is the study of definitive reality, it is fundamental for the elaboration of any concept of education and the variation of metaphysical beliefs led to a different and even educational approach divergent educational systems. One of the issues of metaphysics is the cosmological aspect and cosmology, which according to Knight (2001), consists in 
the study of theories about the origin, nature and development of the universe as an ordered system.

The term "worldview", synonymous with "worldview" or in the German "Weltanschauung", designates a general way of conceiving the world or a perspective on this world (Pessoa Junior, 2006). Crema (1989), defines a worldview, saying that in addition to signifying a world view or conception, it also expresses an attitude towards it. Therefore, it is not a mere abstraction, since the image that man forms of the world has an orientation factor and a shaping and transforming quality of human conduct itself. Implicit in every worldview is a path of action and fulfillment. According to M. Santos (1955), with this systematization it is possible to formulate, not only a general opinion of everything that happens, but also understand and relate an individual fact with the formulated general view of the whole. In the same sense, Sire (2009) stated that:

Few people have anything that comes close to an articulated philosophy, at least as characterized by the great philosophers. Fewer people still have an adequate theology, however, all have a worldview. Whenever we reflect on anything, from casual thinking (where did I leave the watch?) To a deep question (who am I?), We are operating within a framework. In fact, only the hypothesis of a worldview, even if it is basic or simple, allows us to think. (p.15)

Cosmovisão, according to Mendes (2012), is a structure through which the person understands the data of life. A worldview decisively influences how a person sees God, as origins, the question of evil, human nature, values and destiny.

Santos (1955) exemplifies the components inherent to the worldview "In addition to the worldviews provided by science and philosophy, one can also enumerate the det determined by psychology, race, social class, historical culture, as well as those provided by biology, mathematics, physics "(p.19). Buber (1962) did not see the possibility of doing training work without a worldview. Accordingly, Rohr (2013) reinforces that the founding educational work is responsible for the process in which the member of a worldview decides for it, in which he becomes familiar with it, in which he seeks to deepen this knowledge in such a way that he becomes identifies with the repercussions that this vision has on him, in the concreteness of his life. Someone can be born and grow up in a worldview. One can socialize and acculturate in it. But if he does not go through a moment when he decides for himself, she is not really his. He needs to appropriate her in order to recognize her as hers, feeling authentic with him in this experience. As Buber (1962) further exemplifies that formative work educates participants from all worldviews for authenticity and truth. It educates everyone to take their own worldview seriously, starting from the authenticity of the fund and moving towards the truth of the target.

We cannot exclude ourselves. We always carry ourselves, with our historical situation, our concrete experience of ourselves and the world, our horizon of understanding. The concrete pre-understanding that results, even if it is possible, should not be eliminated. It is the indispensable condition for us to be able to ask about man. (Coreth, 1988, p.19)

According to Pestalozzi, cit. by Incontri (1997), about beliefs, moral religion, is the one that leads to moral autonomy, because it represents the valorization of interiority and integrity, through the recognition of the divine essence present in each human being and the proposal of a lifestyle responsible and autonomous. The moral religion defined by Pestalozzi is one that provides the freedom not to be enslaved to one's own instincts and the autonomy to transcend social morality, allowing human beings to act responsibly according to the only true and possible morality that is assumed by the individual conscience.

In line with CRP, LBSE states, in Articles 3 and 4, that one of the guiding principles of the educational system is: "b) to contribute to the achievement of the student, through the full development of personality, the formation of character and citizenship, preparing him for a conscious reflection on spiritual, aesthetic, moral and civic values and providing him with a balanced physical development "(p.6). According to the publication Global competency for an Inclusive World (OECD, 2016), global competence requires numerous skills / abilities, including the ability to understand other people's beliefs and feelings, and to see the world according to their perspectives.

It can be summed up by saying that worldview (world view) is the fundamental cognitive orientation of an individual or of an entire society. This orientation encompasses its natural philosophy, its fundamental, existential, normative values, its emotions and its ethics, its ideology, that is, the image of the world imposed on the people of a nation or community. by which an individual interprets the world and interacts with it.

Therefore, this research also analyzed the students' worldview centered on their beliefs, because, in order to understand what they think and their arguments, it is necessary, first, to take into account the concepts that underlie and guide their conception of man and the world and, therefore, way, they run through beliefs. 


\section{OBJECTIVE}

Identify the worldview of students participating in the study of Portuguese public universities.

\section{KIND OF STUDY}

We used in the scope of this investigation:

1. Qualitative approach, using an interview.

Brief justification for the use of the methodology mentioned above:

- We use the Qualitative methodology, when analyzing the interviews applied to the samples, as they are the main guides, mentors of day-to-day practices, responsible for the curricular plans and vision for the University and the future of the students. As he points out (Morse, 2007) "The qualitative researcher's laboratory is the daily life and cannot be put in a test tube, connected, stopped, manipulated or sent by the sewer. Therefore, the development, description and operationalization of the theory are often the results."

- Phenomenological, as as he reports (Maanen, 1990) "What characterizes it in relation to other qualitative methods, is that it seeks to discover the essence of phenomena, their intrinsic nature and the meaning that humans attribute to them", as well as supports (Fortin, 2009) "The attention of researchers is focused on reality as it is perceived by individuals" This was exactly our intention, to identify the university profile, however, through their feedback.

- Interview, "It has the advantage of including higher responses, greater efficiency in discovering information, low cost, responses obtained quickly and a high response rate, ensuring better data validity." (Fortin, 2009). This instrument fit properly with the objective of this research, which proposed to obtain information from students

\begin{tabular}{|c|c|c|c|c|c|c|}
\hline & Public Universities & $\begin{array}{l}\text { Main } \\
\text { Headquarters }\end{array}$ & Region & Nature & Fundation & Type \\
\hline 1 & Universidade Aberta & Lisboa & Estremadura & University & 1988 & Pública \\
\hline 2 & Universidade dos Açores & Ponta Delgada & Açores & University & 1976 & Pública \\
\hline 3 & Universidade do Algarve & $\underline{\text { Faro }}$ & Algarve & University & 1976 & Pública \\
\hline 4 & $\underline{\text { Universidade de Aveiro }}$ & Aveiro & Beira Litoral & University & 1973 & Pública \\
\hline 5 & Universidade da Beira Interior & $\underline{\text { Covilhã }}$ & Beira Baixa & University & 1986 & Pública \\
\hline 6 & $\underline{\text { Universidade de Coimbra }}$ & Coimbra & Beira Litoral & University & 1290 & Pública \\
\hline 7 & $\underline{\text { Universidade de Évora }}$ & $\underline{\text { Évora }}$ & $\underline{\text { Alto Alentejo }}$ & University & $1973^{[13]}$ & Pública \\
\hline 8 & Universidade de Lisboa & Lisboa & Estremadura & University & 1910 & Pública \\
\hline 9 & Universidade da Madeira & Funchal & Madeira & University & 1988 & Pública \\
\hline 10 & $\underline{\text { Universidade do Minho }}$ & $\underline{\text { Braga }}$ & $\underline{\text { Minho }}$ & University & 1973 & Pública \\
\hline 11 & $\underline{\text { Universidade Nova de Lisboa }}$ & Lisboa & Estremadura & University & 1973 & $\underline{\text { Pública }}$ \\
\hline
\end{tabular}

participating in the study of 10 Portuguese public universities regarding their vision of worldview.

- The Cross-Sectional Study, as described (Harkness, 1995) apud (Fortin, Filion, 2009) "The Cross-Sectional study consists of simultaneously examining one or more sections of the population or several groups of individuals, in a given time, in relation to a phenomenon present at the time of the investigation. The processes considered can be related to age, growth, personal development, etc. " For this reason, our study is also characterized as crosssectional, since the instruments of data collection, such as the interview, were conducted only once, in only a certain time, and thus not longitudinally.

\section{PARTICIPANTS IN THE STUDY}

For our study, it was an accidental and convenience sample by quotas, as exemplified (Fortin, 2009) "The accidental sample is formed by subjects who are present in a specific place, at a precise moment and the quota technique is used to ensure a representation of subgroups or strata of the population. "Exactly like the proposal for this research, where students who were at that time and on that day and only for the quotas were interviewed, that is, using 13 rd year student from 10 of the Portuguese public universities, that is, from the 13 Portuguese public universities, There were 10 universities under study: University of Algarve, University of Aveiro, University of Beira Interior, University of Coimbra, University of Évora, University of Lisbon, University of Trás os Montes and Alto Douro, University of Minho, University of Porto and University Nova de Lisboa. 


\begin{tabular}{|l|l|l|l|l|l|l|}
\hline 12 & $\underline{\text { Universidade do Porto }}$ & $\underline{\text { Porto }}$ & $\underline{\text { Douro Litoral }}$ & University & 1911 & $\underline{\text { Pública }}$ \\
\hline 13 & $\underline{\text { Universidade de Trás-os-Montes e }}$ & $\underline{\text { Vila Real }}$ & $\underline{\text { Trás-os-Montes e Alto }}$ & University & 1986 & $\underline{\text { Pública }}$ \\
& $\underline{\text { Alto Douro }}$ & & $\underline{\text { ouro }}$ & & & \\
\hline
\end{tabular}

\section{RESULTS AND DISCUSSION}

Only because man does not fully understand himself. Just because he remains an enigma and a mystery to himself, just because his knowledge corresponds to not knowing and his self-understanding is at the same time incomprehension, he can and must ask what is specific and specific to his being. (Coreth, 1988, p.11)

the results regarding the content analysis of the interviews conducted with students from the 10 public universities in portugal, the context of this study, will be presented by category and subcategory.

in the total sample, the majority of students were male, 9 boys and 1 girl, falling into the 19-22 age group, all of whom were single.

the categories were pre-established by the researcher on departure and the subcategories emerged from the interviewees' discourse.

category 1: the origin of man. (where we came from?)

regarding this category, in the interviewees' discourse, subcategories emerge. the analysis of these subcategories allows us to verify that the vast majority of the answers are divided between god and evolution. however, they present some nuances like big bang, adam and eve and cells, of which the fragments of the quotes that follow are more expressive:

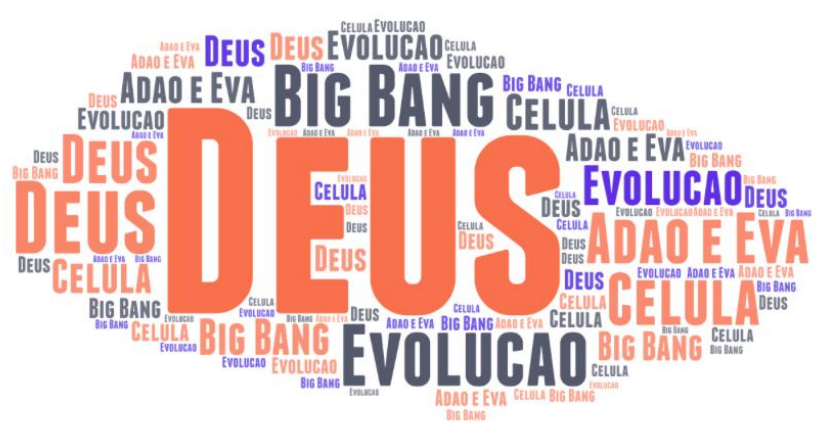

Fig.1: The origin of man. (Where we came from?)

Coreth (1988), says it is a philosophical question of the first Greek thinkers about the arche panton, the principle of all things. And that this question indicates the task that falls to the philosophical thought of all times, that is, to question everything about its principle. He also says that this question is made from man and because of man and made to analyze the whole reality in which man experiences himself, and thus recognize his own place and his mission in that totality of being. The author states that, regardless of how this question is asked or answered, the truth is that this question constitutes an affirmation about man himself and the way he concretely understands himself in his world, in history and in the whole of reality. "Everything we know about man, everything that each man knows about himself, does not correspond to man. What the man is attached to, what the man struggles with, does not identify the man. His origin poses a problem for him "(Jaspers, 1965, p.48).

\section{Category 2: The future of humanity? (Where are we going?)}

As for the argument given by the interviewees about their vision of the future of humanity, they indicate a vision of the future that is heading towards an end, not very optimistic.

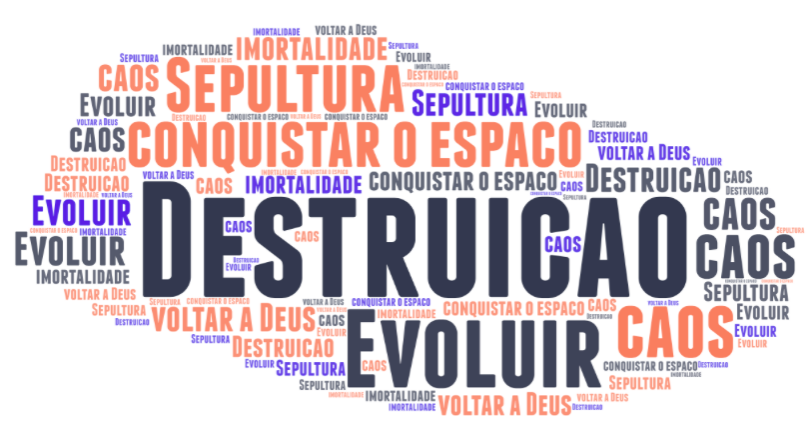

Fig.2: The future of humanity? (Where are we going?)

These results or even the interest of this part of the research go in the direction of what Rohr (2013) says, "the search for a meaning of human life cannot exclude thoughts about the end of life, death, which is part of life" (p.113). As well as:

It is not intended to affirm a scientifically sustainable truth, much less to offend someone in their personal beliefs. These are reflections that we raise in terms of hypotheses, in the sense of possibilities of thought that, as such, open perspectives for analyzing a reality. If we do not want to give up aiming at the fullness of the human in its formation, we need to seek answers to the anxieties that arise around the distance between the fullness as a goal of 
human formation and the finitude of human existence on earth. (Rohr, 2013 p.114)

For Viktor Frankl, a neurologist and psychiatrist, doctor of philosophy, survivor in four concentration camps during World War II, he is a reference in the literature that deals with the question of the meaning of human life, the author says that questioning oneself about the meaning of life consists of what is most human in man, showing a symptom of maturity as, in doing so, the individual is not limited to pre-existing (traditional) ideals and values, but has the courage to seek a personal sense for its existence (Frankl, 1989).

\section{Category 3: The purpose of your existence.}

When asked about the "purpose of existence", a diverse view is perceived, ranging from I don't know, to helping others or personal development.

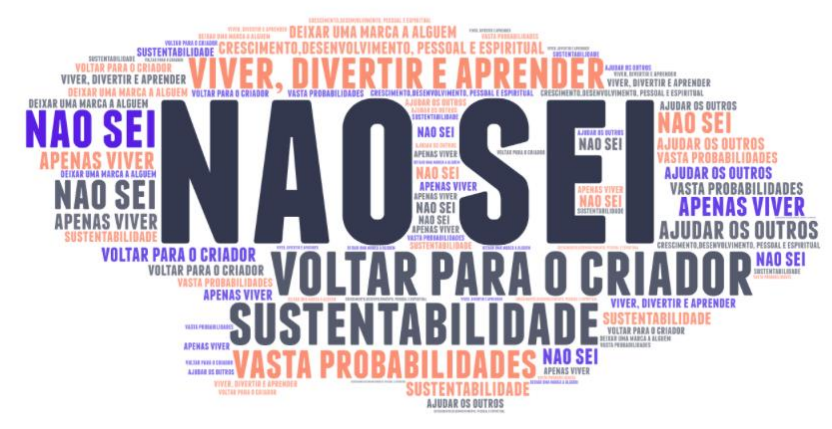

Fig.3: What is the purpose of your existence?

The study or reflection of this theme in education or teaching, is defended by Rohr (2013):

Human life is reoriented to assume the fullness of its dimensions and a new perspective on education is inaugurated, which characterizes the composition of what can be called an educational goal, which presents as a fundamental scope helping the student to realize the meaning of their own life. (p.158)

In this same line of thought, Coreth (1988) states that "man lives in the world and asks for the meaning of his existence. It is an old question from humanity that cannot be reduced to silence "(p.223). The author also pointed out that for Marx, who understood man only as a set of social relations, the question of the meaning of life was a bourgeois prejudice that socialism had to overcome. However, Coreth, affirmed that the individual is not only part of a whole, nor can he see its meaning in submitting to a historical process. And if this answer can suffice while one has a job that satisfies him and gives him a sense, what happens when he has an incurable disease and can no longer work? And what happens when he has severe pain and cannot see any sense in it? And what happens when he walks towards a certain death? Can this sense, of being a function of society, satisfactorily explain the meaning of human existence? (Coreth, 1988). For the author, it is not only about individual existence; the meaning of the whole history of mankind is also at stake, because, from the moment we think where the meaning of all efforts and failed struggles is, blood spilled uselessly, pains and tears spilled in secret, injustices suffered until now and not yet repaired? In his view, then, man is oriented towards an absolute foundation and meaning. Therefore, Coreth (1988) defends the purpose of existence as follows:

Man is faced with the problem of an absolute foundation of meaning, a problem to which he cannot escape. Because of this fact, there is always an authentic experience of meaning based on faith in God. It thus constitutes itself based on faith in God lived and felt in a new intellectual world. This shows that the true origin and that the existential place of the problem of God, of faith in God, lies in the question of the meaning of human existence and that the experience of meaning in God alone reaches its ultimate foundation. (p.229)

Table 1 presents the summary of the categories and subcategories described above.

\begin{tabular}{|l|l|}
\hline Categories & \multicolumn{1}{|c|}{ Subcategories } \\
\hline 1. The origin of man & Interviewee 1) Big Bang and God \\
Interviewee 2) Big Bang \\
Interviewee 3) I don't know \\
Interviewee 4) Evolution \\
Interviewee 5) Cell \\
Interviewee 6) source-God \\
Interviewee 7) Adam and Eve \\
Interviewee 8) Adam and Eve and Evolution \\
Interviewee 9) Evolution \\
\hline
\end{tabular}




\begin{tabular}{|c|c|}
\hline & Interviewee 10) Be divine \\
\hline 2. The future of humanity & $\begin{array}{l}\text { Interviewee 1) Extinction } \\
\text { Interviewee 2) death } \\
\text { Interviewee 3) destruction } \\
\text { Interviewee 4) chaos } \\
\text { Interviewee 5) conquest of other planets } \\
\text { Interviewee 6) return to source } \\
\text { Interviewee 7) immortality } \\
\text { Interviewee 8) destruction } \\
\text { Interviewee 9) Explore other planets } \\
\text { Interviewee 10) Nirvana, evolve. }\end{array}$ \\
\hline 3. Purpose of existence & $\begin{array}{l}\text { Interviewee 1) reaching higher beings } \\
\text { Interviewee 2) sustainability } \\
\text { Interviewee 3) live, have fun and learn } \\
\text { Interviewee 4) a wide range of probabilities } \\
\text { Interviewee 5) I don't know } \\
\text { Interviewee 6) spiritual and personal growth and development } \\
\text { Interviewee 7) leave a mark on someone } \\
\text { Interviewee 8) help others } \\
\text { Interviewee 9) just live } \\
\text { Interviewee 10) I'm looking for }\end{array}$ \\
\hline
\end{tabular}

\section{CONCLUSION}

We were able to identify the students' arguments about their position regarding the worldview in relation to the origin of man, it is divided between Evolution and God.

Regarding the vision of the future, where are we going ?, we mostly identified a not very optimistic vision, more of an absolute end (extinction), chaos and destruction.

About the purpose of existence a very diverse view, most of which I don't know, of those who are looking for their purpose for this life and those who think of developing, having fun and helping others.

We were able to have a minimal notion of the vision of the interviewed students participating in this study, from north to south of the country in relation to their position in the face of the so-called 3 universal questions, of which we all seek an answer and all regardless of whether it is right or wrong we must have our position and conviction.

It is noted, therefore, the need and relevance of an opening so that universities can propose a space, transversal disciplines, developing values, with respect for the holistic being that the student is, also offering an education that is harmonious, with a view to physical, emotional, spiritual growth and helping students to be convinced of their beliefs or even know what they believe, therefore, a curriculum that is not only intellectual is important.

\section{REFERENCES}

[1] Amado, J.S.(2000). "A tecnica de analise de conteúdo.”, Revista Referencia, 5,53-63.

[2] Barreto, M (2006). Teoria e Pratica de uma Educação Integral. Salvador: Sathyarte.

[3] Carmo, H; Ferreira, M.(1998) Metodologia da investigação. Lisboa: Universidade Aberta.

[4] Cazau, P. (2006). Introduccíon a la investigacion en ciencias sociales ( $3^{\mathrm{a}}$ ed.). Buenos Aires.

[5] Chevrier, J. (2003).Investigação social: da problemática à recolha de dados ( $3^{\mathrm{a}}$ ed., pp 64-95). Loures: Lusociência.

[6] Crema, R.(1989). Introdução à Visão Holística: Breve Relato de Viagem do Velho ao Novo Paradigma. 2.ed., São Paulo: Summus, p. 17.

[7] Delors,J (1996).Educação um tesouro a descobrir. Unesco. Lisboa.(2a ed)Edições ASA.

[8] Edgar, Faure (1972). Aprender a ser. Lisboa. Bertrand.

[9] Fava, Rui (2012) Educação 3.0: Como ensinar estudantes com culturas tão diferentes. Cuiabá: Carlini e carniato editorial 
[10] Ferreira, J. A. \& Hood, A. B. (1990) Para a compreensão do desenvolvimento psicossocial de estudante universitário. Revista Portuguesa de Pedagogia, 24,391-406.

[11] Fortin, M.-F. (1999). O processo de investigação: Da concepção à realização. Loures: Lusociências, Edições Técnicas e Cientificas.

[12] Fortin, M.-F. (2003). O processo de investigação: Da concepção à realização. Loures: Lusociências, Edições Técnicas e Cientificas.

[13] Fortin, M.F; Coté.J; Filion.F. (2009). Fundamentos e etapas do processo de investigação. Loures: Lusodidática.

[14] Gauthier, B. (2003). Investigação social: da problemática à recolha de dados ( $3^{\mathrm{a}}$ ed.). Loures: Lusociência.

[15] Giddens, A.(1994). Sociologia. Madrid: Alianza Universidad Textos.

[16] González Rey,F.(2005).Pesquisa qualitativa e subjetividade: Os processos de construção da informação. São Paulo: Pioneira Thomson Learning.

[17] Imbernon,Francisco(ORG)(2000). A educação no século XXI: Os desafios do futuro imediato. 2.ed.Porto Alegre: Artes Medicas.

[18] Jean Marie de Ketele; Xavier Roegiers.(1998). Metodologia de recolha de dados. Lisboa:Instituto Piaget.

[19] Kerlinger, F. N. (1980). Metodologia de pesquisa em Ciências Sociais. São Paulo: EPU.

[20] Lobrot, M (1992). Para que serve a escola?Lisboa: Terramar.

[21] M.J.Sousa; C.S.Baptista.(2011). Como fazer investigação, dissertações, teses e relatórios. 4.ed. Lisboa: Pactor.

[22] Marconi, M: Lakatos, Eva Maria.(1999). Técnicas de pesquisa. 4.ed.Sao Paulo: Atlas.

[23] Maslow, A. (1962).Introdução à psicologia do ser. Rio de Janeiro: Eldorado, 1962.

[24] Morin.Edgar. (1999)Os sete saberes para a educação do futuro. Lisboa. Horizontes Pedagógicos.

[25] Morse, Janice, M.(2007). Metodologia de Investigação qualitativa. Coimbra: Formasau.

[26] Pagan, A.(2009). Ser (animal) humano: Evolucionismo e Criacionismo nas concepções de alguns graduandos de Ciências biológicas. Tese de Doutorado. Faculdade de Educação de São Paulo.

[27] Quivy, R., \& Campenhoudt, L. van. (2008). Manual de investigação em ciências sociais ( $5^{\mathrm{a}} \mathrm{ed}$.). Lisboa: Gradiva.

[28] Rubin, I. S., \& Rubin, H. J. (2004). Qualitative Interviewing: The Art of Hearing Data ( $2^{\mathrm{a}}$ ed.). Thousand Oaks: SAGE.

[29] Sabino, C. A. (1992). El proceso de investigación / Carlos A. Sabino. Caracas: El Cid Editor.

[30] Santos, M. F. dos.(1955). Filosofia e Cosmovisão (Introdução à Filosofia e Visão Geral de Mundo). 2. ed., São Paulo, Logos, p. 123.

[31] Sampieri, R., Fernández-Collado, C., \& B. Lucio, P. (2006). Metodología de la investigación ( $4^{\mathrm{a}}$ ed.). México: McGraww-Hill Interamericana.

[32] Serapioni, M. (2000). Métodos qualitativos e quantitativos na pesquisa social em saúde: algumas estratégias para a integração. Ciência \& Saúde Coletiva, (001), 187-192.
[33] Sousa, A. B. (2005). Investigação em educação. Lisboa: Livros Horizonte.

[34] Vala,J.(1986). "A analise de conteúdo", in: SILVA,A.S; PINTO,J.M.(orgs) Metodologia das ciências sociais. Porto: Afrontamento.

[35] Vogt, W. P., \& JOHNSON, R. B. (2011). Dictionary of statistics \& methodology: A nontechnical guide for the social sciences ( $4^{\circ} \mathrm{ed}$.). Sage Publications, Inc.

[36] Williams, M., \& Vogt, W. P. (2011). The SAGE handbook of innovation in social research methods. London: Sage Publications Ltd.

[37] Wiseman, J.P e Aron, M,S.(1972). Field Reports in Sociology, Londres: Transworld Publishers. 